\title{
Partially disarticulated new Miocene burrower bug (Hemiptera: Heteroptera: Cydnidae) from Cerová (Slovakia) documents occasional preservation of terrestrial arthropods in deep-marine sediments
}

\author{
Peter VRŠANSKÝ ${ }^{1,2, *}$, Jerzy A. LIS ${ }^{3, *}$, JÁn SCHLÖGL ${ }^{4, *}$, Martin GULDAN 5 , TomÁŠ MLYNSKÝ ${ }^{1,6}$, \\ Peter BARNA ${ }^{1}$ and PAVEL ŠTYS ${ }^{7}$ \\ ${ }^{1}$ Earth Science Institute SAS, Dúbravská cesta 9, P.O. Box 106, SK-840 05 Bratislava, Slovak Republic; e-mail: geolvrsa@savba.sk \\ ${ }^{2}$ Arthropoda Laboratory, Paleontological Institute, Russian Academy of Sciences, Profsoyuznaya 123, 117868 Moscow, Russia; \\ e-mail: lab@palaeoentomolog.ru \\ ${ }^{3}$ Department of Biosystematics, Center for Biodiversity Studies, Opole University, Oleska 22, 45-052 Opole, Poland; \\ e-mail: cydnus@uni.opole.pl \\ ${ }^{4}$ Department of Geology and Paleontology, Faculty of Natural Sciences, Comenius University in Bratislava, Mlynská dolina G, \\ SK-842 15 Bratislava, Slovak Republic; e-mail: schlogl@fns.uniba.sk \\ ${ }^{5}$ KVANT, Faculty of Mathematics, Physics and Informatics, Comenius University, Mlynská dolina, SK-842 48 Bratislava, Slovak \\ Republic; e-mail: Martin.Guldan@kvant.sk \\ ${ }^{6}$ Balneological Museum Piešt’any, vila Dr. Lisku, Štefánikova 1, SK-921 01 Piešt’any, Slovak Republic; \\ e-mail: tmlynsky@yahoo.com \\ ${ }^{7}$ Department of Zoology, Charles University, Viničná 7, Praha 2, CZ-128 44 Czech Republic; e-mail: pavelstys@gmail.com
}

Key words. Hemiptera, Heteroptera, Cydnidae, Sehirus, new species, fossil insect, bathyal, Cenozoic, Slovakia, Cerová, confocal profile

\begin{abstract}
The state of preservation of the bug Sehirus carpathiensis J.A. Lis, Vršanský \& Schlögl, sp. n. (Hemiptera: Heteroptera: Cydnidae) from the Lakšárska Nová Ves Formation at Cerová (Slovakia) supports extremely rapid sinking and burial in upper bathyal Early Miocene sediments. The specimen originated from land at most a few kilometers away, but transport via a river can be excluded as the head and wings are still attached. Its most likely source based on fossil flora and the habitat of several living representatives of the genus is a riparian habitat in an adjacent area of land. Phylogenetically the new species is closely related to both Oligocene and living representatives of the genus, thus indicating an early Paleogene origin of the genus (like many other living insect genera). The observations based on two samples from one area (Czech Republic) indicate that terrestrial insects are occasionally preserved in deep marine environments, but overlooked due to their usually fragmentary and obscure nature of the preservation. The newly developed KVANT full-profile confocal measurement revealed a sample roughness $\mathrm{Ra}=1.3-2.0 \mu \mathrm{m}$ and abdomen submerged in the matrix 300 $\mu \mathrm{m}$ deeper than the more rigid pronotum.
\end{abstract}

\section{INTRODUCTION}

The bottom of the sea is among the most common preservation environments of a diversity of fossils, including marine arthropods. Less frequently, such environments, down to $600 \mathrm{~m}$, contain records of extinct terrestrial biota, such as those near the coast of California (Pierce, 1965). Several Lagerstätten are deposited in such environments, often containing fauna and flora from adjacent land such as in diverse Liassic localities in Germany, England (e.g., Holzmaden and Dobbertin; Ansorge, 1996, 2003, 2004) and Denmark (Rust, 1998). On the Kerch Peninsula in the Crimea a spectacularly preserved specimen of an unidentified Tarkhanian insect was recorded in association with the luminescent deep water fish, Vinciguerria merklini Danilchenko, 1946 (Photichthyidae) (see Zherikhin, 2002).

In Central Europe, particularly in the Carpathian region, deep-water sediments are often represented by flysh de- posits, which rarely also contain terrestrial insects, such as the elytron of a described beetle (Prokop et al., 2004). The present find of a cydnid bug is associated with a diverse flora, including plant fructification organs of herbaceous monocots and also an assemblage of the remains of riparian plants (Kvaček et al., 2014), which are regarded as a good indicator of its source ecosystem as the living representatives of the genus live in such habitat.

Insects are somewhat more frequently preserved in deepwater sediments than other wingless terrestrial arthropods (Zherikhin, 2002) due to self-dispersion by flight, although this specimen represents a poorly flying robust and heavy bug.

The lifestyle of the extant burrowing bugs is burrowing in soil and feeding on roots. However, some of the bugs in the subfamily Sehirinae are not fossorial and feed on above-ground parts of a diverse range of herbaceous plants (e.g., Lis et al., 2000; see also below).

\footnotetext{
* Authors contributed equally to this work.
} 
The fossil record of the family Cydnidae comprises 69 taxa; 68 species in the EDNA fossil insect database (URL: edna.palass-hosting.org; accessed 21 May 2015) (33 species originally placed in Cydnidae and 35 initially in Pentatomidae), and Paleofroeschnerius magnus Schaefer, 1986 (Schaefer \& Crepet, 1986) which is absent from this database. Palaeobiology database (URL: paleobiodb.org; accessed 24 May 2015) contains all those 69 species.

The cydnid fossil record [earliest Cretaceous to Recent (Popov, 1986; Yao et al., 2007, 2010)] includes a possible fossil burrow (Smith et al., 2008).

In contrast to the subtropical climate at the source locality of the new species, the present range of the genus is the Palearctic, but with part of its range in the subtropical zone, e.g., Turkey and Iran (Lis 1999, 2006). On the other hand, a fossil (Miocene) limnephilid caddisfly specimen from this region (found at Plášt'ovce Member that possibly originated from the up to $4,000 \mathrm{~m}$ high Miocene Śtiavnica stratovolcano located nearly $30 \mathrm{~km}$ to the north: Chernyshev et al., 2013; Sukatscheva et al., 2006) is probably not a representative of an exclusively subtropical element as its recent close relatives are associated with evergreen plant assemblages and are autumnal mass flying cryophilic species.

This is the first species assigned to the subfamily Sehirinae recorded from the Miocene worldwide. Eighteen species of burrower bugs including 4 of the genus Sehirus Amyot \& Serville, 1843 (Lis, 1999, 2006) live in the Carpathians today.

\section{GEOGRAPHICAL AND GEOLOGICAL SETTING}

The specimen was collected in the western part of the Slovak Republic at Cerová. The outcrop is situated in the foothills of the Malé Karpaty Mountains. These mountains form the eastern margin of the middle part of the Vienna Basin (Fig. 1), which was part of the Central Paratethys Sea during the Miocene. Karpatian (late Burdigalian) sediments, assigned to the Lakšárska Nová Ves Formation (Špička \& Zapletalová, 1964), are well exposed in a former clay pit. The sediments consist of massive, locally laminated, calcareous clays and clayey silts with thin tempestite intercalations (up to $10 \mathrm{~mm}$ thick) and several thin sandstone/siltstone layers. The actual section is almost $20 \mathrm{~m}$ thick. The macrofossil assemblage consists of vertebrates, mainly teleosts, and a wide spectrum of invertebrates - bivalves, gastropods, scaphopods (Harzhauser et al., 2011), cephalopods (Schlögl et al., 2011), decapods (Hyžný \& Schlögl, 2011; Hyžný et al., 2014), isopods (Hyžný et al., 2013), barnacles (Harzhauser \& Schlögl, 2012), regular and irregular echinoids, asteroids, siliceous sponges (Lukowiak et al., 2013), bryozoans, and solitary corals (JS unpubl. observ.). Fossil plant remains are also locally abundant (Kvaček et al., 2014). Microfossil assemblages include benthic and planktonic foraminifera, radiolarians, sponge spicules, ostracods, crinoid ossicles, coleoid statoliths, fish otoliths, shark teeth (Underwood \& Schlögl, 2013) and locally an extremely abundant microflora.
These clays and silts were deposited under upper bathyal conditions in a relatively oxygen-depleted environment (Schlögl et al., 2011). Foraminifera assemblages from the interval 14-20 (Fig. 1C) were analyzed using the two-step depth equations of Hohenegger (2005), which yielded a palaeodepth range between 240 and $330 \mathrm{~m}$ (Schlögl et al., 2011). As there is no significant change in facies throughout the section we also assume a similar palaeodepth for the lower intervals. In addition, gastropod and bivalve assemblages, sharks, decapods and siliceous sponge assemblages also imply bathyal conditions.

The exceptional preservation of animals that are easily disarticulated, such as ghost shrimps, minute pilumnid crabs, cirolanid isopods and soft-boddied demosponges, indicate a relatively high net sedimentation rate (Hyžný \& Schlögl, 2011; Hyžný et al., 2013; Łukowiak et al., 2013). Thin sandstone/siltstone layers (up to $5 \mathrm{~cm}$ thick), silt "pavements" or laterally restricted thin silt lenses generally very poor in organic remains can be interpreted as distal turbiditic deposits. Thin laminae up to $10 \mathrm{~mm}$ in thickness, rich in molluscs, echinoderms and wood debris, most probably represent tempestite deposits. These frequently contain mainly one or two fossil groups, most commonly irregular echinoids and/or pteropods. Deposits also contain resedimented microfossils eroded from land areas surrounding the Vienna Basin (Pipík et al., 2010). These along with plant material were apparently transported into the basin from adjacent areas of land by rivers.

Biostratigraphy is based on foraminifera. Co-occurrence of the foraminifera Uvigerina graciliformis Papp \& Turnovsky, 1953 and Globigerinoides bisphericus Todd, 1954 and the absence of the genus Praeorbulina Olsson, 1964 suggest late Karpatian age for the deposits (Berggren et al., 1995; Cicha \& Rögl, 2003; see also Schlögl et al., 2011). The regional Paratethyan Karpatian stage is generally thought to be the time-equivalent of the latest Burdigalian (Rögl et al., 2003; Piller et al., 2007; see also Hohenegger et al., 2014).

\section{MATERIAL AND METHODS}

Unique specimen (deposited in the Slovak National Museum - SNM, under the catalogue no. Z 38494/1-2) preserved as both positive and negative imprints comes from the silty/sandy lamina with tiny fragments of mollusks and wood debris near level 29 (Fig. 1).

Drawing represents a manually redrawn photograph corrected based on the specimen.

Photographs were taken using a LEICA MZ6 binocular microscope with an attached EC3 camera. Illumination was provided by an EUROMEX cold light source with "goose necks" directed from the side. To achieve better details and depth of focus, the specimen was photographed from different positions (12 for body positive, 4 for wing positive, 3 for body negative, 4 for wing negative, 2 for head negative) using a higher magnification, and several differently focused photographs were taken from each position (body positive $4-10$, wing positive $7-9$, body negative $5-11$, wing negative $3-8$, head details 7 and 10). Photographs were combined using CombineZP software (functions "Allign and Ballance Used Frames (Thorough)" and "Pyramid Do Stack"). Pho- 

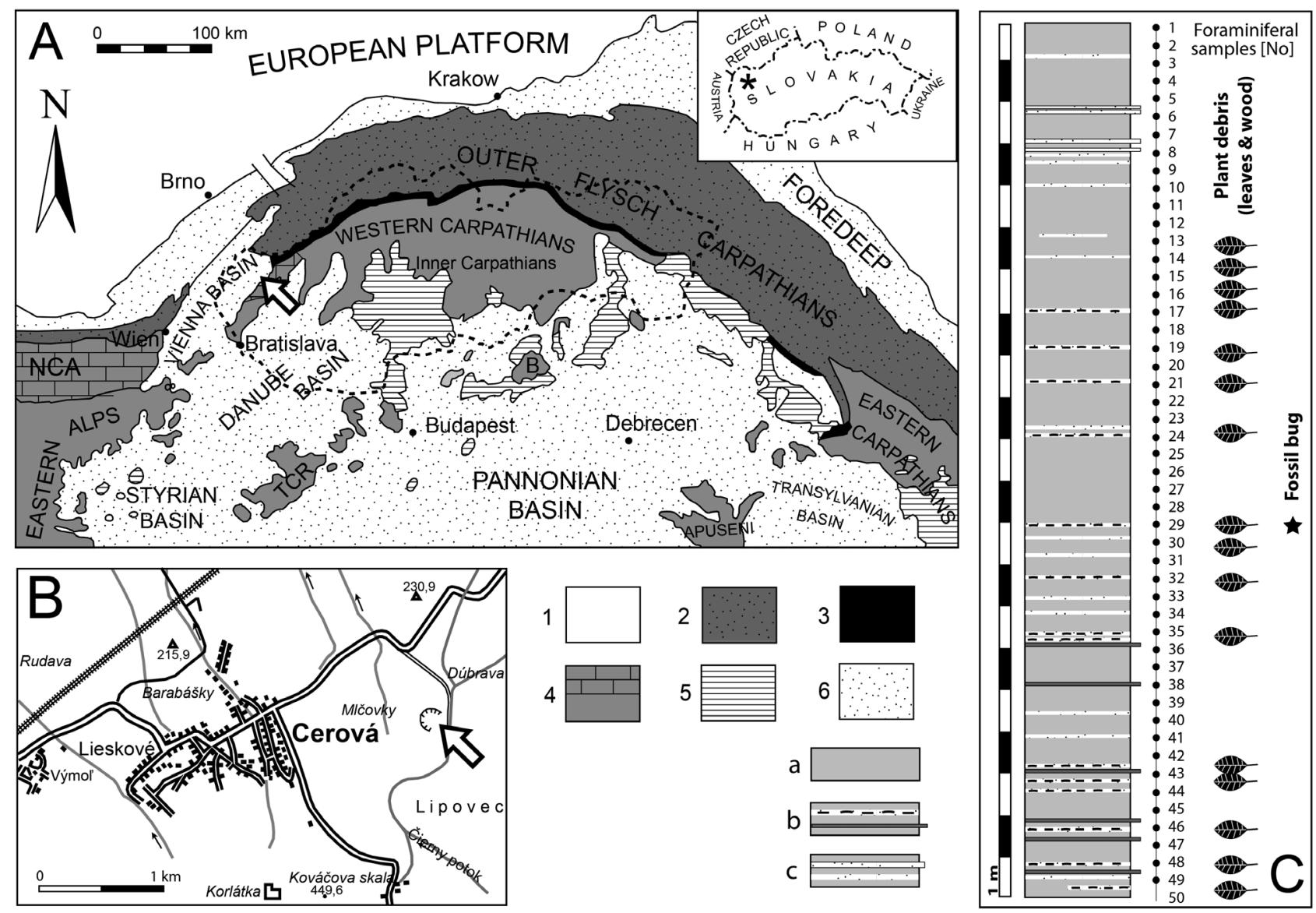

a

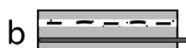

C

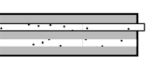

Fig. 1. A - location of the Vienna Basin in the Carpathian-Pannonian system (1, European platform units; 2, Carpathian-Alpine externides; 3, Pieniny Klippen Belt; 4, Alpian-Carpathian-Dinaride and Pannonian internids; 5, Neogene volcanics; 6, Neogene basins; B, Bükk; NCA, Northern Calcareous Alps; TCR, Transdanubian Central Range); B - location of the clay pit at Cerová, indicated by arrow; $\mathrm{C}$ - simplified section through the clay pit (a, massive calcareous clay; $\mathrm{b}$, thin tempestite layers with plant debris, and lithified clayey silt layers; c, thin siltstone/sandstone layers, and silt lenses) (modified after Kvaček et al., 2014).

tographs were subsequently enhanced and merged using Adobe Photoshop CS5 image processing software.

Confocal measurements were made in the submicron range using an ad hoc developed program KVANT (both the profilometer hardware and software used here for the first time revealed the perspective and state of preservation of the sedimentary materials) with a confocaler light probe, resolution $0.4 \mu \mathrm{m}$ in $\mathrm{Z}$ axis (light source Internal white LED; Sensor type Confocal chromatic distance meter; spot diameter $9 \mu \mathrm{m}$ ). Profile is obtained point by point by moving the sample and keeping the position of the probe fixed (confocal light reflection technology allowed the measurement of both matt and shiny surfaces). Measurement was done in two pre-defined matrix movement schemes. A profile processor was used to process, manipulate, measure and export the measured profile data. It offered a dual-view representation of the data: 2D monochromatic for examining the fine detail and a 3D model for viewing the profile data as three-dimensional objects with colour separation of the profile in the $\mathrm{Z}$ axis. We also used plane correction, peak filters, line profiles and line roughness.

Morphological nomenclature for the cephalic chaetotaxy follows Lis \& Pluot-Sigwalt (2002), for the mesothoracic wing venation Lis (2002), and for the metathoracic scent efferent system Kment \& Vilímová (2010).

\section{RESULTS}

\section{Systematics}

Order: Hemiptera Linnaeus, 1758

\section{Suborder: Heteroptera Latreille, 1810}

Infraorder: Pentatomomorpha Leston, Pendergast \& Southwood, 1954

Superfamily: Pentatomoidea Leach, 1815

Family: Cydnidae Billberg, 1820

Subfamily: Sehirinae Amyot \& Serville, 1843

Tribe: Sehirini Amyot \& Serville, 1843

Genus: Sehirus Amyot \& Serville, 1843

Type species. Cimex morio Linnaeus, 1761, subsequently designated by Reuter, 1888: 414.

Composition. Sehirus aeneus Walker, 1867; S. cypriacus Dohrn, 1860; S. dissimilis Horváth, 1919; S. horvathi Reuter, 1900; S. luctuosus Mulsant \& Rey, 1866; S. lygaeus Statz, 1950 (fossil); S. morio (Linnaeus, 1761); S. ovatus (Herrich-Schäffer, 1840); S. paludosus Statz, 1950 (fossil); S. parens Mulsant \& Rey, 1866; S. planiceps Horváth, 1895; S. robustus Horváth, 1895; S. spinitibialis Statz, 1950 (fossil); S. tibialis Puton, 1892; S. xinjiangensis Jorigtoo \& Nonnaizab, 1995. 

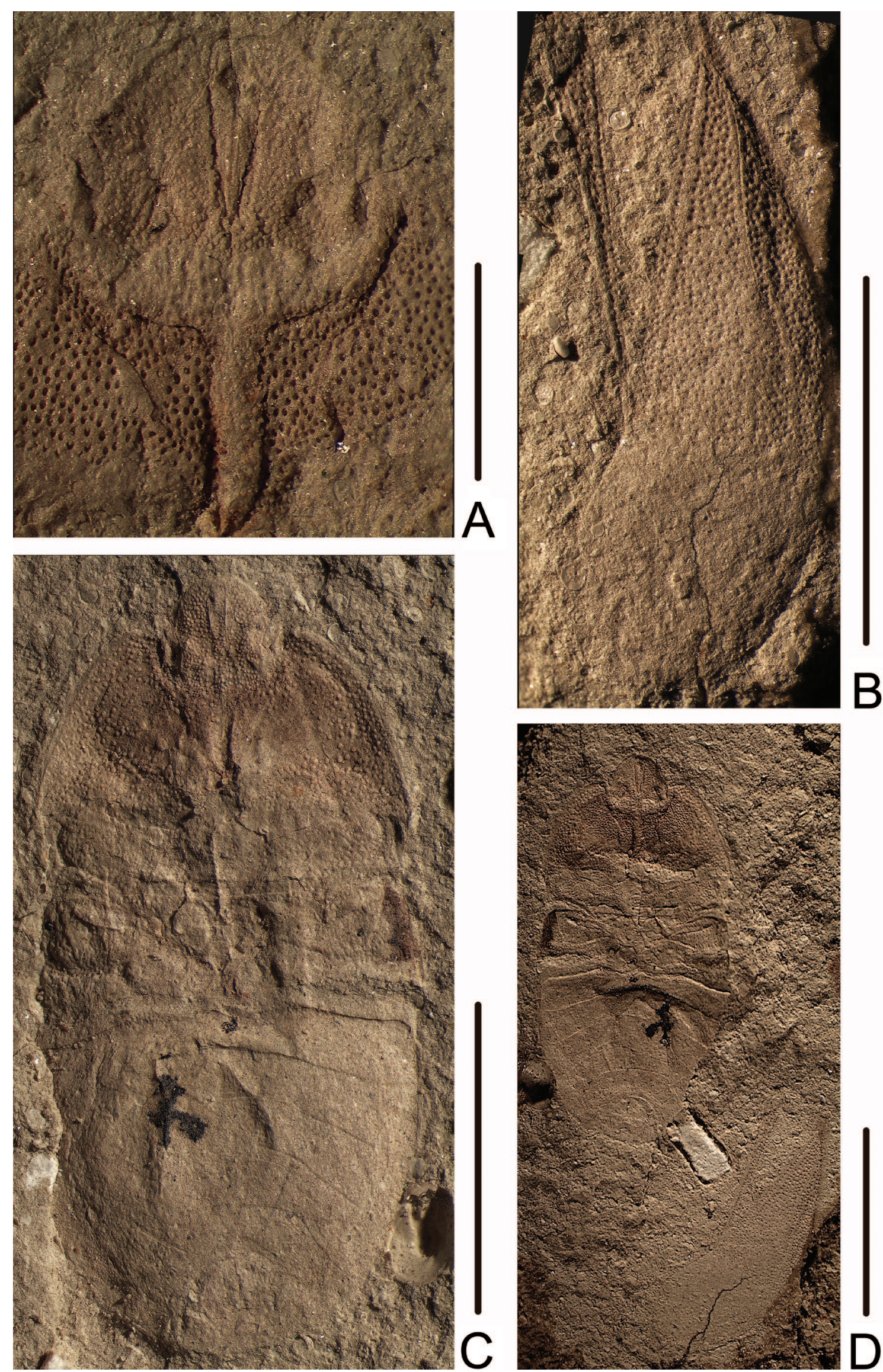

Fig. 2. Composite photographs of the female of Sehirus carpathiensis J.A. Lis, Vršanský \& Schlögl, sp. n. A - head; B - forewing; C-D - complete specimen SNM Z 38494/1-2 (土). Scale bars: A, 2 mm; B-D, 5 mm. 

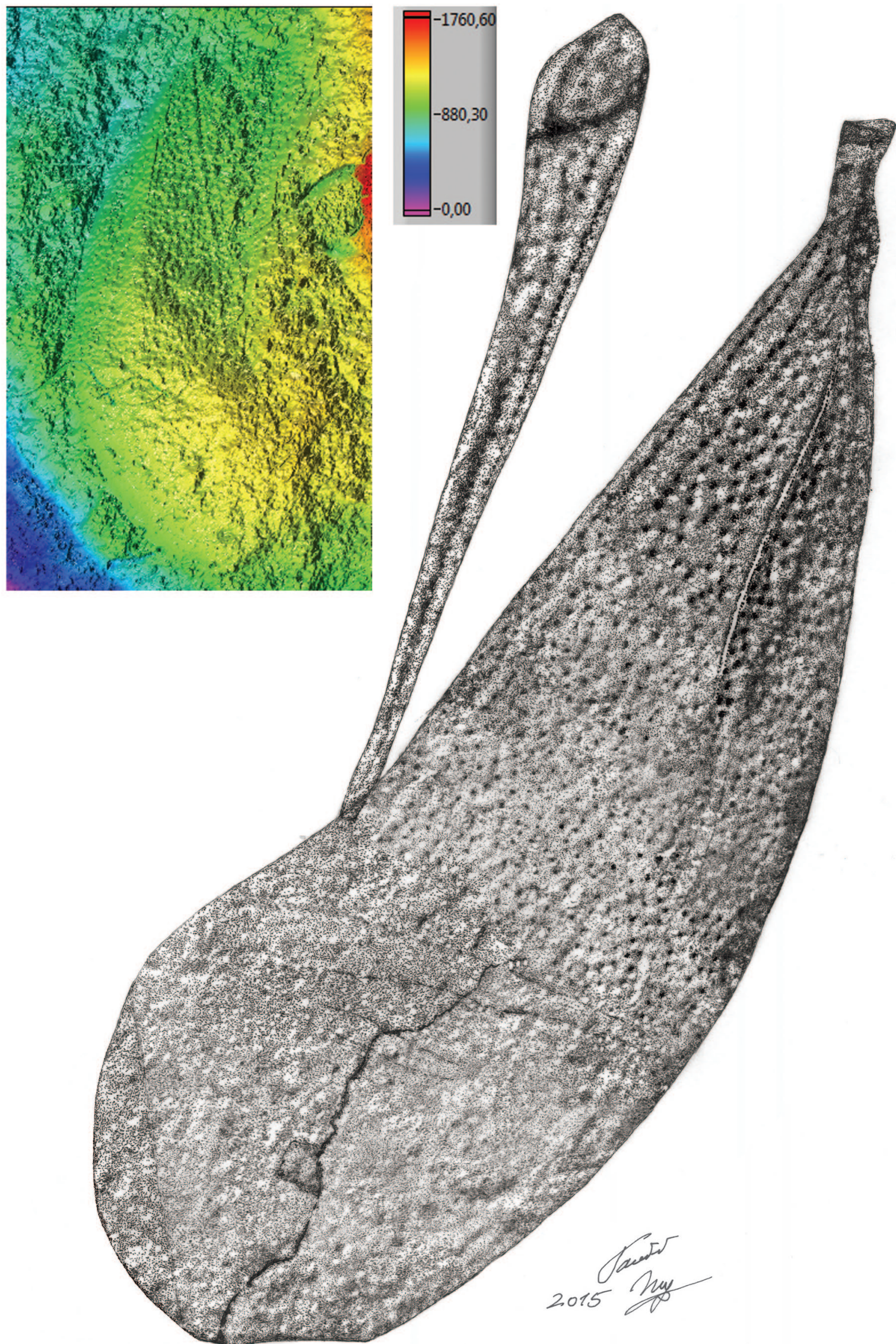

Fig. 3. Illustration based on a redrawn photograph and profile of the female of Sehirus carpathiensis J.A. Lis, Vršanský \& Schlögl, sp. n. Forewing SNM Z 38494/1, length $9.2 \mathrm{~mm}$. 


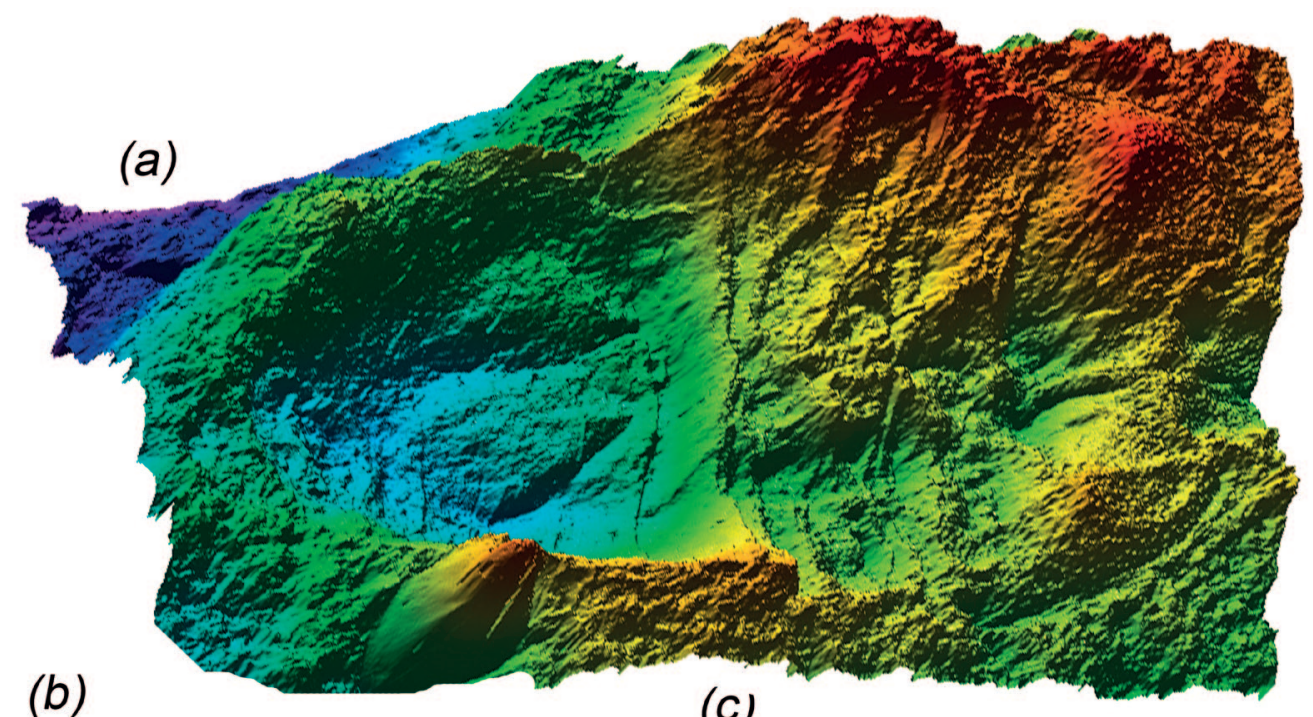

(b)

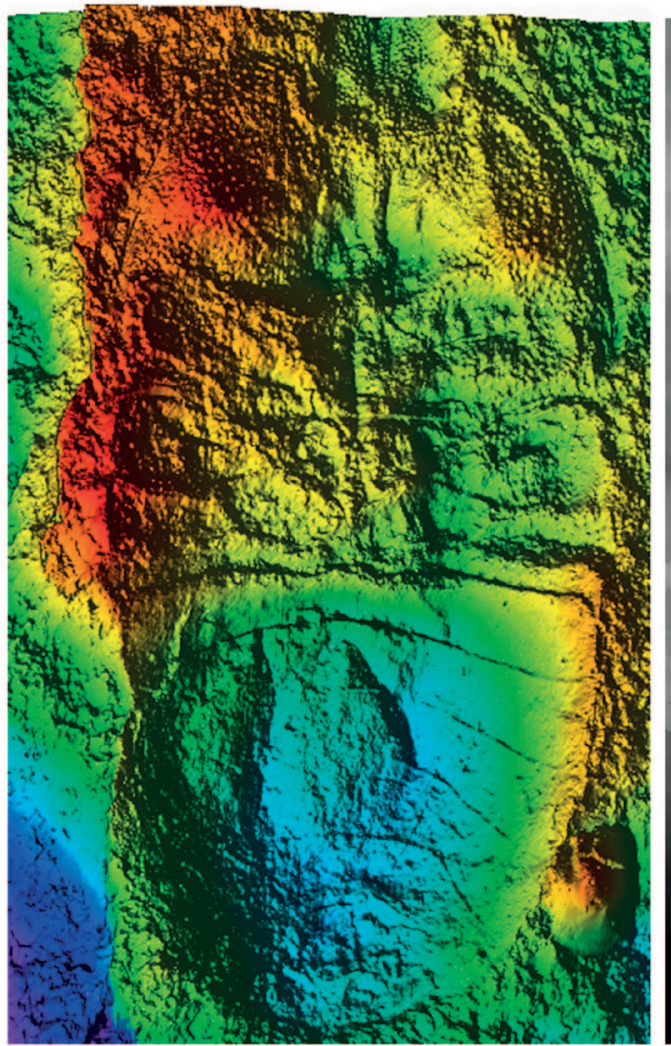

(c)
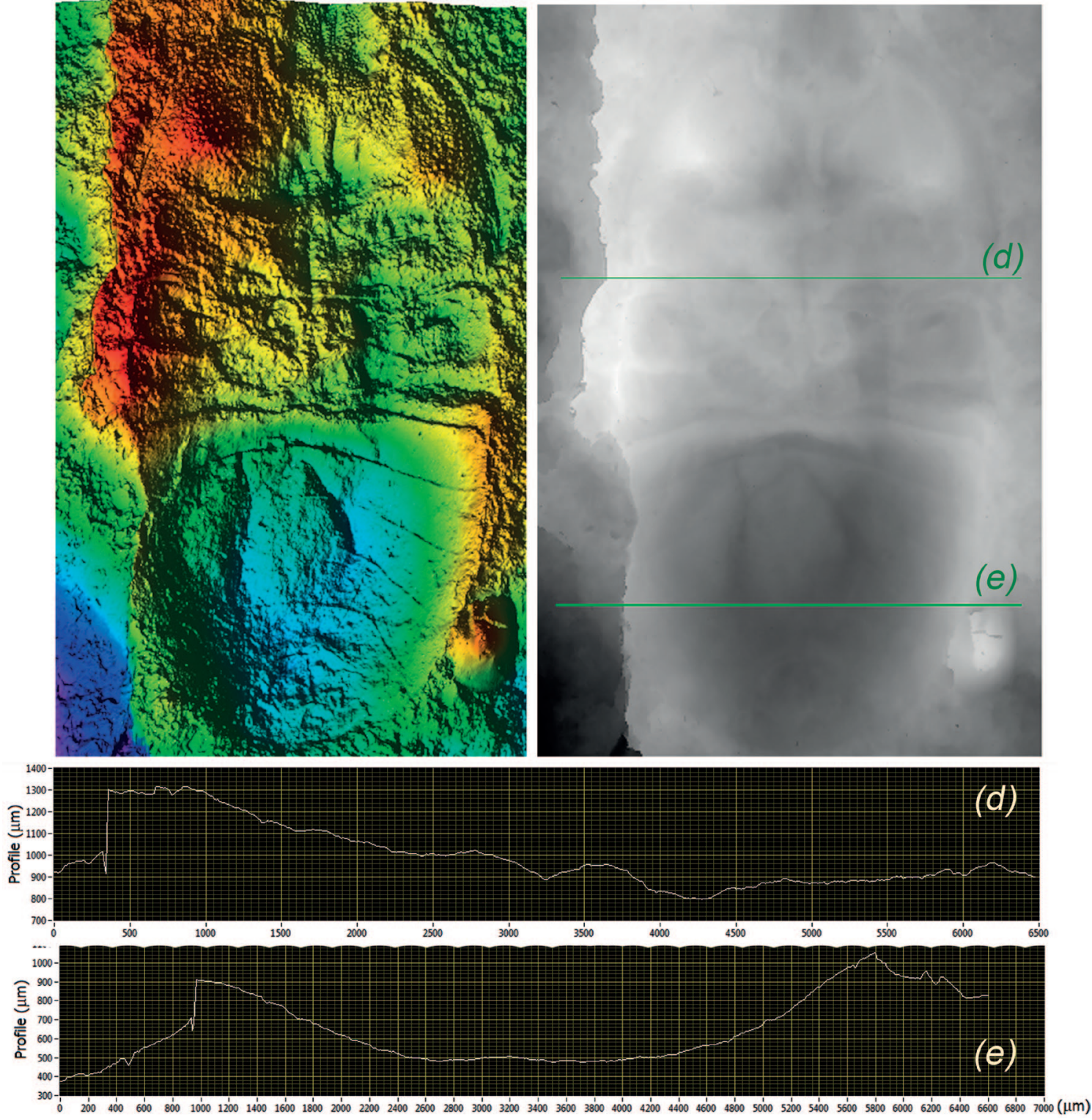

Fig. 4. Body profile of the female of Sehirus carpathiensis J.A. Lis, Vršanský \& Schlögl, sp. n., sample SNM Z 38494/1-2 ( \pm ). Roughness, identical in matrix and specimen $\mathrm{Ra}=1.3-2 \mu \mathrm{m}$ (roughness according to ISO 4288). Abdomen is roughly $300 \mu \mathrm{m}$ deeper in the sediment than the pronotum. Confocal profilometer (d-e-reverse). Body length/width: 10.8/5.2 mm. 


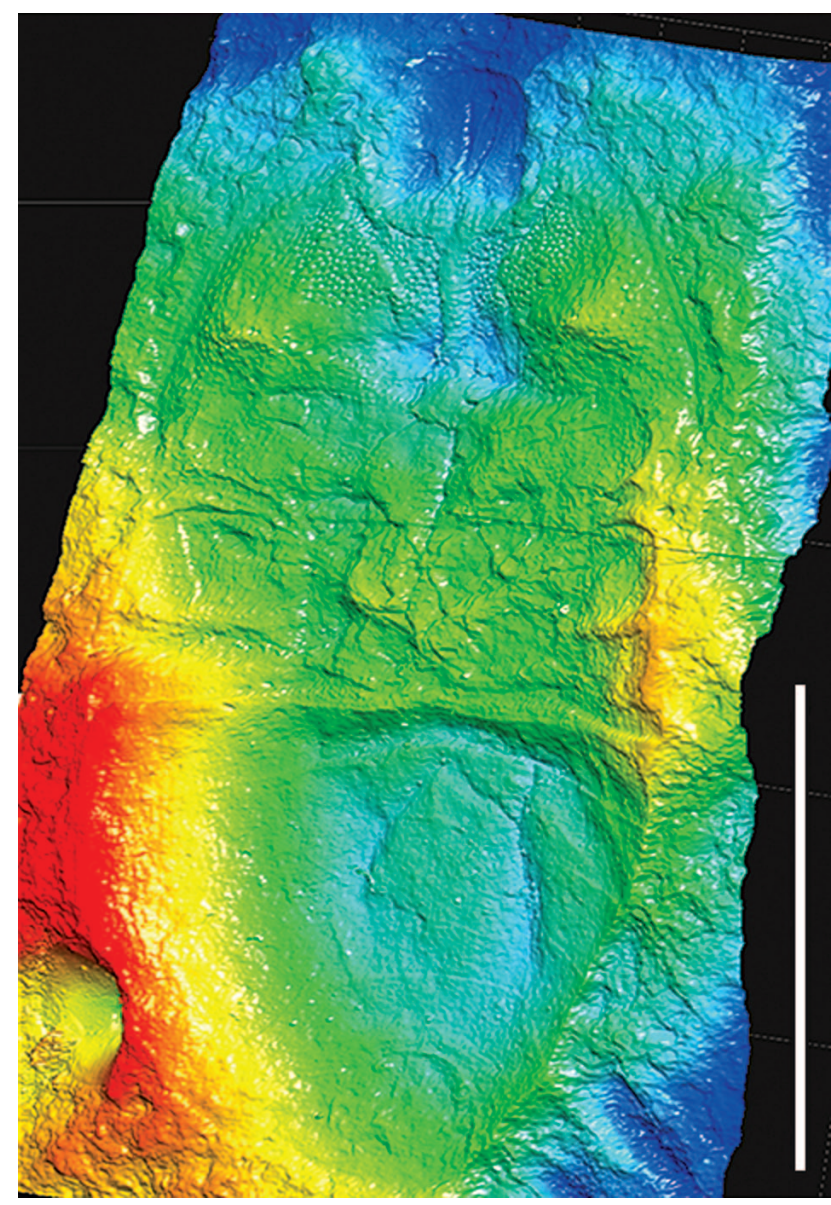

Fig. 5. Body profile of the female of Sehirus carpathiensis J.A. Lis, Vršanský \& Schlögl, sp. n., sample SNM Z 38494/1-2 (negative). Roughness, identical in matrix and specimen $\mathrm{Ra}=1.3-2$ $\mu \mathrm{m}$ (roughness according to ISO 4288). Abdomen is roughly 300 $\mu \mathrm{m}$ deeper in the sediment than the pronotum. Confocal profilometer. Right lateral view with length compressed (real length/ width: 10.8/5.2 mm). Scale bar $5 \mathrm{~mm}$.

Geographic range of extant species. Species of the genus Sehirus occur in the Palearctic Region ranging from North Africa, through Europe and the Middle East to West Siberia and North West China (Lis, 2006). The single American Sehirus cinctus (Palisot, 1811) probably belongs to another genus (Lis et al., in prep.).

Stratigraphic range. Oligocene - Recent.

Diagnosis. Body convex, uniformly dark coloured, its dorsal surface densely coarsely punctured; head without setae on clypeus and paraclypei; eyes not protruding, immersed in head at least by half of their length; costal margin of hemelytron without setigerous punctures; mesopleural and metapleural evaporatoria large and well developed, peritreme elongated, scimitar-shaped and rounded apically.

Sehirus carpathiensis J.A. Lis, Vršanský \& Schlögl, sp. n. (Figs 2-6)

Holotype female. SNM Z 38494/1-2 ( \pm - positive and negative imprints).

Type locality. Cerová, Malé Karpaty Mts, western Slovakia.

Type horizon. Late Karpatian, Early Miocene, Lakšárska Nová Ves Formation.
Differential diagnosis. Within the genus, the new species can be differentiated by its free clypeus that is only a little shorter than the paraclypei, whereas in the most closely related species $S$. robustus the clypeus is significantly shorter and concealed by the longer paraclypei. Other species within this genus have weaker puncturation and except for $S$. morio (with a shorter rostrum) are significantly smaller. For a comparison of the characters see Discussion.

Description. Body elongate-oval, $10.8 \mathrm{~mm}$ in length, $5.2 \mathrm{~mm}$ in width (at the widest part of the pronotum).

Head a little broader than long, its ventral surface with dense coarse punctures; clypeus free, only a little shorter than paraclypei; rostrum reaches posterior coxae; setae on lateral margins of head absent (neither peg-like nor hairlike setae present); eyes depressed, deformed (however, the general shape of the head indicates that the shape of the eyes is typical for the genus Sehirus).

Pronotum distinctly broader than long; its anterior margin deeply sinuate in the middle to accommodate the head; lateral pronotal margins broadly rounded, without setigerous punctures (no hair-like setae present). Propleuron deeply punctured almost over its entire surface, except for a small area in the anterior convexity of each propleural depression.

Hemelytron length $9.2 \mathrm{~mm}$. Corium densely and almost evenly punctured; clavus with four rows of punctures, one almost complete reaching two-thirds along the length of the clavus, one complete reaching the apex of the clavus, and two incomplete reaching halfway along the clavus. Meso- and exocorium densely and coarsely punctured; mesocorium with two rows of punctures paralleling the clavocorial suture. Costal margins without setigerous punctures (no hair-like setae present). Venation of the corium as follows: $\mathrm{C}$ entirely coalescent with $\mathrm{Sc}, \mathrm{R}$ coalescent with $\mathrm{M}$ in its basal half, the apical part of $\mathrm{M}$ clearly visible, $\mathrm{Cu}$ widely separated from $\mathrm{R}+\mathrm{M}, 1 \mathrm{~A}$ present, $2 \mathrm{~A}$ absent.

Mesopleural and metapleural evaporatoria typical of the genus Sehirus, i.e., large and well developed; peritreme elongated, scimitar-shaped, apically rounded (see Fig. 5); peritremal surface impunctate; ostiolar plate punctured; metathoracic spiracle elongated, well visible. Abdominal sterna punctate laterally.

Character of preservation. Body visible in ventral view, except for hemelytron for which its dorsal surface is visible. Hemelytral corium broken into two pieces, i.e., the clavus is separated from the remaining part including the mesocorium, exocorium and membrane. Legs not preserved.

Derivation of name. Named after the Carpathians - the source mountain chain; adjective.

\section{DISCUSSION}

The new fossil is classified in the genus Sehirus on the basis of the following characters: (1) head shape and chaetotaxy; (2) body puncturation; (3) venation of the corium; (4) shape of meso- and metathoracic evaporatoria, and (5) shape of the peritreme. It is the fourth fossil species of the genus Sehirus, after S. lygaeus, S. paludosus and S. spini- 


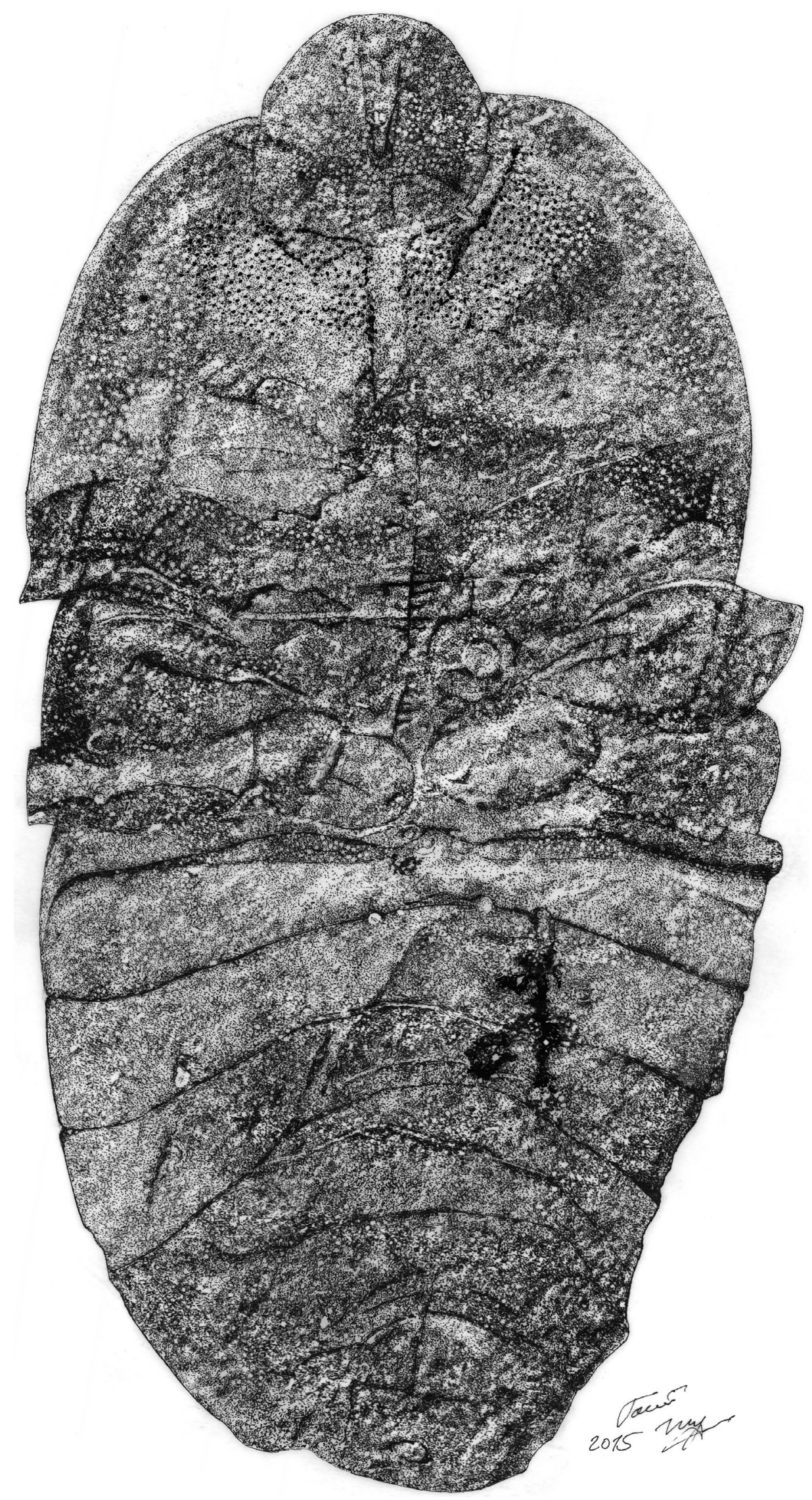

Fig. 6. Illustration based on a manually redrawn photograph of the female body of Sehirus carpathiensis J.A. Lis, Vršanský \& Schlögl, sp. n., SNM Z 38494/1. Body length/width: 10.8/5.2 mm. 
tibialis, which were described from the Rott Formation in Germany (Oligocene) (Statz \& Wagner, 1950). The newly described species, apart from its geological age, differs also from all those already described fossil species in terms of its body size (S. carpathiensis $-10.8 \mathrm{~mm}$ in length, 5.2 $\mathrm{mm}$ in width, hemelytron length $9.2 \mathrm{~mm}$; S. lygaeus -9.8 $\mathrm{mm}$ in length, $5.0 \mathrm{~mm}$ in width, hemelytron length $7.2 \mathrm{~mm}$; S. paludosus $-6.8 \mathrm{~mm}$ in length, $3.9 \mathrm{~mm}$ in width, hemelytron length $4.5 \mathrm{~mm}$; $S$. spinitibialis $-7.4 \mathrm{~mm}$ in length, $4.0 \mathrm{~mm}$ in width, hemelytron length $6.2 \mathrm{~mm}$ ).

Moreover, its clypeus is only a little shorter than the paraclypei, whereas in S. lygaeus it is much shorter and in both $S$. spinitibialis and $S$. paludosus a little longer than the paraclypei.

In its body size and puncturation, as well as the shape of its head and length of its rostrum, S. carpathiensis seems to be most closely related to the extant Palearctic $S$. robustus, which occurs in Armenia, Azerbaidjan, Georgia, Iran, Iraq and Turkey (Lis, 2006).

Both the fossil S. carpathiensis and the extant S. robustus are the largest species so far recorded in this genus (body length: $10.8 \mathrm{~mm}$ in $S$. carpathiensis, 10.0-12.0 $\mathrm{mm}$ in S. robustus). There are records of large specimens of $S$. morio, with female body length occasionally reaching $12.0 \mathrm{~mm}$ (Stichel, 1961; Lis et al., 2012), but $S$. morio is morphologically quite different from the new fossil species, especially in its weaker body puncturation and shorter rostrum, which at most reaches the middle coxae.

Although S. carpathiensis and S. robustus seem to be very closely related, they can be separated from each other by the length of their paraclypei and clypeus ( $S$. carpathiensis - clypeus free, only a little shorter than paraclypei; $S$. robustus - apex of clypeus concealed by paraclypei, the latter distinctly longer than the former).

Unfortunately, imperfect preservation (lack of the dorsal body side imprint, except for the hemelytron) limits the number of characters that can be used to separate these two species. Insect species would seldom remain unchanged for several million years [although such Miocene examples do exist, for instance the Chiapas amber termite $\mathrm{Ka}$ lotermes nigritus Snyder, 1946 (Kalotermitidae) still living in South America (Zherikhin, 1970), an undescribed Dominican amber mayfly now living in the Neotropics, or living hydrophiloid beetle Helophorus sibiricus (Motschulsky, 1860) found at Kartashevo (Fikáček et al., 2011)], and most probably many other characters would have been found if a dorsal imprint of the newly described fossil species had also been preserved. Thus, in the current state of knowledge the difference in the clypeus is sufficient.

The host plants of the majority of the living species of the genus Sehirus belong to the family Boraginaceae, although they are also recorded on Scrophulariaceae (e.g., Verbascum) and Caryophyllaceae (e.g., Cerastium). Importantly, Sehirus species are found mainly on Boraginaceae usually growing in herbaceous and ruderal vegetation in dry, warm and predominantly sandy habitats, including also those in riparian zones, where they live on Myosotis, Anchusa and Echium (Stehlík \& Vavrínová, 1993, Wach- man et al., 2008). At Cerová, plant remains are usually associated with tempestitic layers, but sometimes they are also found scattered within the background clay deposits. State of preservation often precludes more detailed determination as many of them have been extensively damaged, possibly during transport. However, a complex analysis of the whole herbaceus and palynologic assemblage revealed interesting information about this allochtonous vegetation (Kvaček et al., 2014) represented by herbaceous monocots, including Paleotriticum and Potamogeton sp., ferns (Lygodium) and arboreal elements such as Liquidambar and Craigia, which are mainly found growing in ecotones of aquatic and azonal terrestrial environments, such as backswamp and riparian vegetation. The analogy with Spartina type grasses allows the reconstruction of the herbaceous vegetation as coastal salt marshes similar to the brackish marshes in tidal wetlands in North America (Kvaček et al., 2014). We assume that the fossil riparian zones indicated by the local plant assemblages might be the source vegetation of this new species.

Complete relief maps (i.e., full-profiles based on individual confocal profiles) (Figs 3A-5) measured for the first time in this study revealed important additional data for the specimen, including outlines that are unrecognizable using standard optical methods as the roughness of the sample and surrounding area remains constant at $\mathrm{Ra}=$ 1.3-2.0. As an example, the significantly deeper submersion of abdomen (by $0.3 \mathrm{~mm}$ compared with the remaining body) within the matrix may indicate specimen- and/ or species-specific preservation properties and the method seems promising for analysis of other sedimentary fossil insects, especially those preserved in masses such as cockroaches at Yixian (Wei \& Ren, 2013). Observation of partial or even complete non-deformed 3D preservation of sediment-preserved insects such as those at Crato (Vršanský, 2003, Figs 24-26; Grimaldi, 2003; Lee, 2014) is by no means easy or trivial. This type of analysis is also suitable for other semi-planar fossil groups.

ACKNOWLEDGEMENTS. We thank three anonymous reviewers for their keen revision and Y.A. Popov (PIN, Moscow) for establishing contacts. This work was supported by the Slovak Research and Development Agency under the contract No. APVV0436-12, APVV-0644-10, and UNESCO-Amba (MVTS); VEGA 2/0125/09, 0012-14. PV designed the research and wrote paper, JAL provided the final identification, systematic description and comparison, JS discovered the specimen and provided the locality and palaeoecological data, TM, PB and MG provided illustrations, composite photographs and profile measurements, PŠ provided the initial determination, edited the text and reviewed the literature.

\section{REFERENCES}

ANSORGE J. 1996: Insekten aus dem oberen Lias von Grimmen (Vorpommern, Norddeutschland). - Neue Paläontol. Abh. 2: $1-132$.

Ansorge J. 2003: Insects from the Lower Toarcian of Middle Europe and England. — Acta Zool. Cracov. (Suppl.) 46: 291-310. Ansorge J. 2004: Insekten aus Liasgeoden der Ahrensburger Geschiebesippe - mit einem Ausblick auf locale Anreicherungen 
von Liasgeoden in Mecklenburg-Vorpommern. - Arch. Geschiebek. 3: 779-784.

Berggren W.A., Kent D.V., Swisher C.C. \& Augry M.P. 1995: A revised Cenozoic geochronology and chronostratigraphy. In Berggren W.A., Kent D.V., Aubry M.-P. \& Hardenbol J. (eds): Geochronology, Time Scales and Global Stratigraphic Correlation. SEPM (Society for Sedimentary Geology), Special Publication 54, Tulsa, pp. 129-212.

Chernyshev I.V., KoneČnÝ V., LeXa J., Kovalenker V.A., Jeleñ S., Lebedev V.A. \& Goltsman Yu.V. 2013: K-Ar and Rb-Sr geochronology and evolution of the Štiavnica Stratovolcano, Central Slovakia. - Geol. Carpath. 64: 327-351.

Cicha I. \& Rögl F. 2003: Definition of the Karpatian stage. In Brzobohatý R., Cicha I., Kováč M. \& Rögl F. (eds): The Karpatian, a Lower Miocene Stage of the Central Paratethys. Masaryk University, Brno, pp. 15-20.

FiKÁČeK M., Prokin A. \& Angus R.B. 2011: A long-living species of the hydrophiloid beetles: Helophorus sibiricus from the early Miocene deposits of Kartashevo (Siberia, Russia). ZooKeys 130: 239-254.

GRIMALDI D. 2003: A revision of Cretaceous mantises and their relationships, including new taxa (Insecta: Dictyoptera: Mantodea). - Am. Mus. Novit. 3412: 1-47.

Harzhauser M. \& Schlögl J. 2012: Lepadiform and scalpelliform barnacles from the Oligocene and Miocene of the Paratethys Sea. - Palaeontology 55: 923-936.

Harzhauser M., Mandic O. \& Schlögl J. 2011: A late Burdigalian bathyal mollusc fauna from the Vienna Basin (Slovak Republic, Karpatian). - Geol. Carpath. 62: 211-231.

HoHENEGGER J. 2005: Estimation of environmental paleogradient values based on presence/absence data: a case study using benthic foraminifera for paleodepth estimation. - Palaeogeogr. Palaeoecol. 217: 115-130.

Hohenegger J., Ćrić S. \& Wagreich M. 2014: Timing of the Middle Miocene Badenian stage of the Central Paratethys. Geol. Carpath. 65: 55-66.

HYŽNÝ M. \& Schlögl J. 2011: An Early Miocene deep-water decapod crustacean faunule from the Vienna Basin (Western Carpathians, Slovakia). - Palaeontology 54: 323-349.

HYžNÝ M., BRUCE N.L. \& SCHLÖGL J. 2013: An appraisal of the fossil record for the Cirolanidae (Malacostraca: Peracarida: Isopoda: Cymothoida), with a description of a new cirolanid isopod crustacean from the Early Miocene of the Vienna Basin (Western Carpathians). - Palaeontology 56: 615-630.

HyžNÝ M., GaŠparič R., Robins C.M. \& SChlögl J. 2014: Miocene squat lobsters (Decapoda, Anomura, Galatheoidea) of the Central Paratethys - a review, with description of a new species of Munidopsis. In Fraaije R.H.B., Hyžný M., Jagt J.W.M., Krobicki M. \& Van Bakel B.W.M. (eds): Proceedings of the 5th Symposium on Mesozoic and Cenozoic Decapod Crustaceans, Krakow, Poland, 2013: A tribute to Pál Mihály Müller. - Scripta Geol. 147: 241-267.

KMENT P. \& VilímovÁ J. 2010: Thoracic scent efferent system of Pentatomoidea (Hemiptera: Heteroptera): a review of terminology. - Zootaxa 2706: 1-77.

Kvaček Z., Teodoridis V., Kováčová M., Schlögl J. \& Sitár V. 2014: Lower Miocene plant assemblage with coastal-marsh herbaceous monocots from the Vienna Basin (Slovakia). Geol. Carpath. 65: 229-241.

LeE S.-W. 2014: New Lower Cretaceous basal mantodean (Insecta) from the Crato Formation (NE Brazil). - Geol. Carpath. 65: $285-292$.

Lis J.A. 1999: Burrower bugs of the Old World - a catalogue (Hemiptera: Heteroptera: Cydnidae). — Genus 10: 165-249.
Lis J.A. 2002: The mesothoracic wing and its phylogenetic significance in Cydnidae (Hemiptera: Heteroptera: Pentatomoidea). - Pol. J. Entomol. 71: 43-71.

Lis J.A. 2006: Cydnidae Billberg, 1820 - burrowing bugs (burrower bugs). In Aukema B. \& Rieger C. (eds): Catalogue of the Heteroptera of the Palaearctic Region. Vol. 5. Pentatomomorpha II. The Netherlands Entomological Society, Wageningen, pp. 119-147.

Lis J.A. \& Pluot-Sigwalt D. 2002: Nymphal and adult cephalic chaetotaxy of the Cydnidae (Hemiptera: Heteroptera), and its adaptive, taxonomic and phylogenetic significance. - Eur. J. Entomol. 99: 99-109.

Lis J.A., Becker M. \& Schaefer C.W. 2000: Chapter 12. Burrower bugs (Cydnidae). In Schaefer C.W. \& Panizzi A.R. (eds): Heteroptera of Economic Importance. CRC Press, Boca Raton, pp. 405-419.

Lis J.A., Lis B. \& Ziaja D. 2012: Heteroptera Poloniae 2. Pentatomoidea część I. Plataspidae, Thyreocoridae, Cydnidae, Acanthosomatidae, Scutelleridae. Opole University, 144 pp.

Łukowiak M., Pisera A. \& Schlögl J. 2013: Bathyal sponges from the late Early Miocene of the Vienna Basin (central Paratethys, Slovakia). - Palaeontol. Zh. 88: 263-277.

OLsson R.K. 1964: Praeorbulina Olsson, a new foraminiferal genus. - J. Paleontol. 38: 770-771.

PAPP A. \& TuRnovski K. 1953: Die Entwicklung der Uvigerinen im Vindobon (Helvet und Torton) des Wiener Beckens. - Jb. Geol. Bundesanst. (A) 91: 117-142.

PierCe W.D. 1965: Fossil arthropods of California. 26. Three new fossil insect sites in California. - Bull. Sth. Calif. Acad. Sci. 64: 157-162.

Piller W.E., Harzhauser M. \& Mandic O. 2007: Miocene Central Paratethys stratigraphy - current status and future directions. - Stratigraphy 4: 151-168.

PiPík R., SChlÖgl J. \& Colin J.-P. 2010: Finding of the Purbeckian limnic Ostracoda in the Early Miocene marine deposits of the Vienna Basin, Slovakia - paleogeographic implications. In Kýška-Pipík R., Starek D. \& Staňová S. (eds): The 4th International Workshop on the Neogene from the Central and SouthEastern Europe, Abstracts and Guide of Excursion. Matej Bel University, Banská Bystrica, pp. 33-34.

Popov Y.A. 1986: Peloridiina (= Coleorrhyncha) et Cimicina (= Heteroptera). In Rasnitsyn A.P. (ed.): Insects in Early Cretaceous Ecosystems of Western Mongolia. Nauka, Moscow, pp. 50-83 [in Russian].

Prokop J., Nel A., Hajek J. \& Bubik I. 2004: First record of a fossil beetle (Coleoptera, Haliplidae) from the basal Paleocene flysch sediments in the Magura Unit (Outer Western Carpathians, Moravia). - Geol. Carpath. 55: 469-473.

Reuter O.M. 1888: Revisio synonymica heteropterorum Palaearcticorum quae descripserunt auctores vetustiores (Linnaeus 1758 - Latreille 1806), Parts I, II. - Acta Soc. Sci. Fenn. 15: 241-315, 443-812.

RöGl F., Ćorić S., Daxner-Höck G., Harzhauser M., Mandic O., ŠvÁBENICKÁ L. \& ZORN I. 2003: Correlation of the Karpatian stage. In Brzobohatý R., Cicha I., Kováč M. \& Rögl F. (eds): The Karpatian, a Lower Miocene Stage of the Central Paratethys. Masaryk University, Brno, pp. 27-34.

Rust J. 1998: Biostratinomie von Insecten aus der Fur-Formation von Dämemark (Moler, oberes Paläozen/unteres Eozän). Paläontol. Z. 72: 41-58.

Schaefer C.W. \& Crepet W.L. 1986: A new burrower bug (Heteroptera: Cydnidae) from the Paleocene/Eocene of Tennessee. — J. N. Y. Entomol. Soc. 94: 296-300. 
Statz G. \& Wagner E. 1950: Geocorisae (Landwanzen) aus den Oberoligocanen Ablagerungen von Rott. - Palaeontogr. Abt. (A) 98: 97-136.

STEHLík J.L. \& VAVŘínOvÁ I. 1993: Results of the investigations on Heteroptera in Slovakia made by the Moravian Museum (Pentatomoidea II). - Acta Mus. Morav. (Sci. Nat.) 77[1992]: 157-208.

Stichel W. 1961: Illustrierte Bestimmungstabellen der Wanzen. II. Europa (Hemiptera - Heteroptera Europae), Vol. 4. 22. Heft. Pentatomomorpha, Cydnidae (2), Plataspididae. By the author, Berlin-Hermsdorf, pp. 667-700.

SukatcheVa I.D., Szalma Š., VRŠanský P., Chalupová B., Golej M., Labajová E. \& SmreČKová M. 2006: Caddis-fly (Insecta: Trichoptera) from Badenian volcano-sedimentary succession (Western Carpathians, Slovakia). — Geol. Carpath. 57: 531534.

Schlögl J., Chirat R., Balter V., Joachimski M., HudáčKová N. \& Quillévéré F. 2011: Aturia of the Miocene Paratethys: An exceptional window in nautilid habitat and lifestyle. Palaeogeogr. Palaeoclimatol. Palaeoecol. 308: 330-338.

Smith J.J., Hasiotis S.T., Kraus M.J. \& Woody D.T. 2008: Naktodemasis bowni: New ichnogenus and ichnospecies for adhesive meniscate burrows (AMB), and paleoenvironmental implications, Paleogene Willwood Formation, Bighorn Basin, Wyoming. - J. Paleontol. 82: 267-278.

ŠPIČKA V. \& ZAPLETALOVÁ I. 1964: Nástin korelace karpatu v československé části vídeňské pánve [Outline of the correlation of the Karpatian in the Czechoslovak part of the Vienna Basin]. — Sbor. Geol. Vèd (G) 8: 125-160 [in Czech].
Underwood C.J. \& SChLögl J. 2013: Deep water chondrichthyans from the Early Miocene of the Vienna Basin (Central Paratethys, Slovakia). - Acta Palaeontol. Pol. 58: 487-509.

VRŠANSKÝ P. 2003: Umenocoleoidea - an amazing lineage of aberrant insects (Insecta, Blattaria). - AMBA Proj. 7: 1-32.

Wachmann E., Melber A. \& Deckert J. 2008: Wanzen. Band 4. Pentatomomorpha II. Pentatomoidea. Cydnidae, Thyreocoridae, Plataspidae, Acanthosomatidae, Scutelleridae, Pentatomidae. In Dahl F. (ed.): Die Tierwelt Deutschlands 81. Goecke \& Evers, Keltern, 230 pp.

WeI D.-D. \& Ren D. 2013: Completely preserved cockroaches of the family Mesoblattinidae from the Upper Jurassic-Lower Cretaceous Yixian formation (Liaoning Province, NE China). - Geol. Carpath. 64: 291-304.

Yao Y.-Z., CAI W.-Z. \& Ren D. 2007: The first fossil Cydnidae (Hemiptera: Pentatomoidea) from the Late Mesozoic of China. - Zootaxa 1388: 59-68.

Yao Y.-Z., Ren D., Shin C.-K. \& Zhang W.-T. 2010: Chapter 15. Heteroptera - smelly defence or piercing offense. In Dong R., Shih C.-K., Gao T.-P., Yao Y.-Z. \& Zhao Y.-Y. (eds): Silent Stories - Insect Fossil Treasures from Dinosaur Era of the Northeastern China. Science Press, Beijing, pp. 139-157.

ZHERIKHIN V.V. 1970: Zoogeographical relation of Paleogene insects. In Lectures on the Twelfth Annual Readings in Memory of N.A. Kholodkovsky, 14 April 1969. Nauka, Leningrad, pp. 29-88 [in Russian].

ZHERIKHIN V.V. 2002: 1.4. Pattern of insect burial and conservation. In Rasnitsyn A.P. \& Quicke D.L.J. (eds): History of Insects. Kluwer, Dodrecht, pp. 17-63.

Received April 20, 2015; revised and accepted June 12, 2015 Prepublished online August 27, 2015 